\author{
Vesna Bulatović* \\ University of Montenegro \\ Faculty of Philology \\ Nikšić, Montenegro
}

\title{
ENGLISH LEXICAL CORRESPONDENTS OF ASPECTUAL PAIRS IN SERBO-CROATIAN
}

\begin{abstract}
This paper looks into some English lexical correspondents of aspectual pairs in Serbo-Croatian (SC). Because SC and English are diametrically opposed in terms of how overtly they express aspect, SC and English are usually seen as typical representatives of languages with and without aspect, respectively. In SC, the aspectual dichotomy is expressed by the following three instruments in the following order of frequency: a) pairs of lexically related verbs; b) biaspectual verbs, and c) pairs of different verbs. Our analysis shows that 'aspectless' English uses the same three instruments but in a different order of frequency. Most English verbs are biaspectual, i.e. their aspectual interpretation depends on a number of factors outside the verb. This study focuses on the other two instruments. Several different types of such lexical means for the expression of aspectual dichotomy in English are identified according to the lexical and morphological relations between their members.
\end{abstract}

Key words: perfectivity, imperfectivity, aspect, lexical aspect, aspectual pair

E-mail address: vesnabu@ucg.ac.me 


\section{Introduction}

Extensive typological studies (Dahl 1985; Groot and Tommola 1984; Bybee and Dahl 1989; Thelin 1990) have proven that aspect is a universal linguistic category, which confirms that the distinction between perfectivity and imperfectivity is relevant for all languages. Languages employ different, language-specific means to express this distinction, but just because something is language-specific does not mean it is unique. The languages analyzed in this study, SC $^{1}$ and English, have more than one means that can be used for this purpose (see §2.1. and §2.2. for SC and English, respectively). This study ${ }^{2}$ uses SC as a starting point for the analysis of these different means in English, and the lexical means in particular. But what do we mean by imperfectivity and perfectivity?

Imperfectivity is associated with the 'internal structure' of the situation (Comrie 1976: 24), 'internal change' (Hlebec 1990: 17), a 'situation enduring without change' (Galton 1984: 9), 'durativity' (Verkuyl 1972), and 'incompletion' (Kabakčiev 2000).

Perfectivity, on the other hand, is associated with the concepts of the 'indivisible whole' (Dahl 1984: 13; Comrie 1976; Arad 1998: 274), 'change' (Galton 1984: 9), 'transition' from one state to another (Hlebec 1990: 91), 'non-durativity' (Verkuyl 1972), and 'completion' (Kabakčiev 2000).

These meanings can be expressed perfectly clearly at the level of the verbal lexeme in various languages, as is illustrated in Spanish hablar ipf3 'talk', English rage ipf, Polish wierzyć ipf 'believe', SC sipati ipf 'pour', German

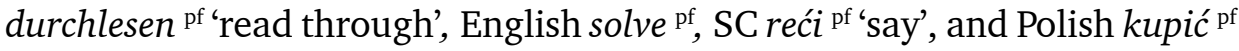
'buy'.

Although some of the major works on aspectology focus equally on the universal and the language-specific properties (Comrie 1976, 1985; Dahl

1 Serbo-Croatian ('SC') is a South Slavic language whose name fell out of use with the disintegration of the former Yugoslavia. It is a polycentric language with four varieties: Serbian, Croatian, Bosnian, and Montenegrin. The author uses the term Serbo-Croatian here because the corpus used is composed of Croatian or Serbian English and Croatian English dictionaries. The name issue is irrelevant for this study because the four languages do not differ in the manner by which they express aspect.

2 The present study is a summary of a much more extensive study conducted under the supervision of Professor Hlebec. The author expresses her deep appreciation for Professor Hlebec's selfless support and dedication.

3 The superscript abbreviations ipf and pf will be inserted after respective examples to indicate the imperfective or perfective aspectual value of a given verb or verb phrase. 
Vesna Bulatović: English Lexical Correspondents of Aspectual Pairs...

1985; Groot and Tommola 1984; Brinton 1988; Bybee and Dahl 1989; Thelin 1990), aspect has for many remained the Slavic 'thing' probably because in this language group it is overtly expressed through affixation and stem alternation. Yet, some of the most important developments in aspectology are due to the extremely detailed research done on English, previously thought to be an aspectless language (Zandvoort 1962: 10).

Vendler's time-schemata (see also Ryle 1949; Vendler 1967; Kenny 1963; Dowty 1977, 1979; Mourelatos 1978) or aspectual classes (with imperfective states and activities on the one hand, and perfective accomplishments and achievements on the other) were presented as universal categories. Indeed, they have been tested and proven reliable on the material of other languages (see Novakov 1991 for Serbian, for example). Vendler's accomplishments proved instrumental to the further development of aspectology because most of the examples he used were not verbs but verb phrases composed of activities and specified arguments. Vendler's examples show that the same verb, such as draw, can be both an activity and an accomplishment depending on the internal argument. For example, draw ipf is an activity and draw a circle ${ }^{\mathrm{pf}}$ is an accomplishment because the temporal bounds of the referent of a circle are mapped onto the referent of the activity of drawing which might otherwise go on indefinitely (Verkyl 1971; Kabakčiev 2000). In simpler terms, the activity draw cannot go on forever since there is a terminus, or telos, expressed by the internal argument $a$ circle. The same accomplishment is expressed by a prefixed perfective in most Slavic languages, e.g. Serbian nacrtati ${ }^{\mathrm{pf}}$ or Russian нарисовать 'draw'. The Dutch linguist Verkuyl explored this further in order to analyze the impact of arguments and other elements on the aspectual interpretation of verbs, which is known as the compositional approach to aspect (Verkuyl 1972, 1989). Much of the work done by formal semanticists (Partee 1999; Rothstein 2004) focused on how exactly spatio-temporal boundedness affects verbs, and verbs of creation in particular (also known as 'incremental theme verbs'). There is a general understanding that most English verbs can lend themselves to almost any aspectual interpretation in context ${ }^{4}$. Cognitivists (Langacker 1987, 1991,

However, it is ironic that to this day all the wonderful achievements in aspectology have not made their way into the modern grammars of English. They still focus on the overt expression of aspect in English, mainly on the expression of the imperfective meaning through the progressive morpheme. There is no mention of the role of articles in the specification of arguments or the explication of aspect. In addition, the simple fact that 
2008; Lakoff and Johnson 1980; Zhang 1995) take this fact into account when they say that the verbal system is a continuum in which there is a group of typical aterminative verbs, and a group of typical terminative verbs, while all other verbs remain in between. These 'fuzzy areas' are created because there is no clear distinction between the conceptualization of boundedness and non-boundedness on the one hand, and the aspectual meanings of perfectivity and imperfectivity on the other (Zhang 1995: 34).

Is there any point then in examining and describing the aspectual value of English verbs when every verb can have any aspectual value? We believe there is. If the majority of English verbs are biaspectual, it is worth examining the following:

a) Are there any verbs in English that cannot express both aspectual values ${ }^{5}$

b) If so, are some of these verbs correlated to some other means that can be used to express the 'missing' aspectual value,

c) What is it that makes these situations so different that different linguistic means have to be used in English to express the two aspectual values, and

d) If such pairs of aspectually related verbs are established in English, what can be done to improve the description of that segment of the English verbal system?

To respond to these questions, we proceed as follows. Section Two briefly discusses the explication of aspectual distinctions in SC and English. The methodology and the results of the analysis are presented in Section Three. The observations are elaborated in Section Four, and a number of conclusions and suggestions are presented in Section Five.

\section{Aspect}

In this section we briefly describe the key instruments that SC and English employ in the specification of aspectual semantics. The key difference is that in SC, rich verbal morphology compensates for the absence of articles (which is crucial for the specification of arguments), while English, because

the non-progressive morpheme can also express the imperfective meaning is often left to the learner's intuition.

5 This excludes generic and habitual meanings. 
it has articles, does not need to shift the burden of specification from the arguments to the verbs.

Affixation is crucial for the expression of aspect in SC. How productive some of the SC prefixes are is best demonstrated by the number of verbs in our sample (see §3.1.) that share their initials with these prefixes. The contribution of the prefixes do-, iz-, na-, o-, pro-, pre-, raz-, s-, $u$-, and $z a-$ is clearly shown in Figure 1.

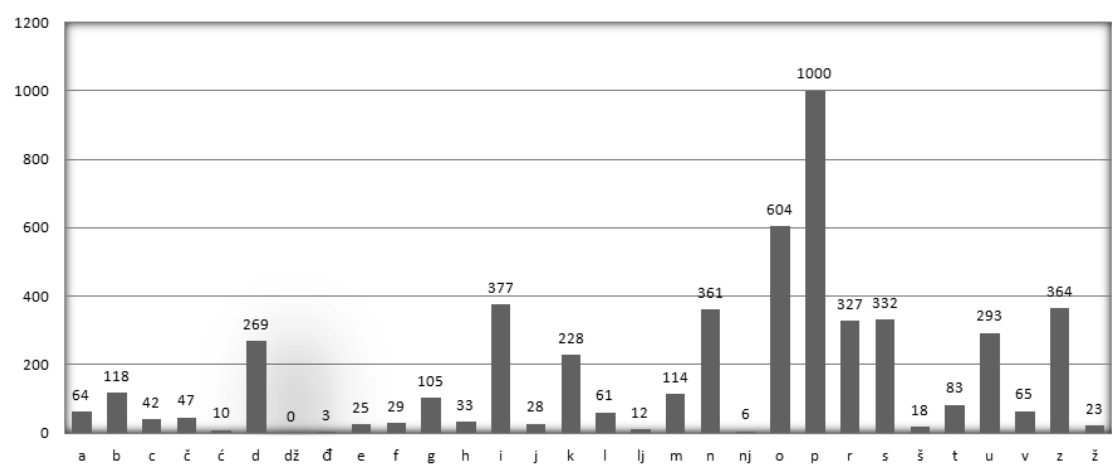

Figure 1. The number of items in our sample in alphabetical order

\subsection{Aspect in SC}

Imperfective verbs in SC are states, znati 'know', activities, govoriti 'speak', and secondary activities (formed from momentary verbs with the addition of infixes to express repetition, such as kuckati 'knock'). Some states cannot be perfectivized, such as sastojati se 'consist', while some can be used to yield perfective verbs that express the moment when a state began. For example, znati 'know' has its perfective counterpart saznati 'learn/come to know'. Most activities get their perfective counterparts in the form of verbs with the same base, modified by affixation, such as pjevati 'sing' : otpjevati 'finish singing'. Some activities are formed from achievements through affixation, such as udarati 'hit (repeatedly)' from udariti 'hit (once)'. There are also cases when aspectual meanings are expressed by two different lexemes, such as govoriti 'speak' : reći 'say', or slušati 'listen' : čuti 'hear'. Conversely, there are cases when a single lexeme is used to express both the imperfective and the perfective meaning. This is a case of aspectual polysemy, and such verbs are called biaspectual verbs. For example, čestitati 'congratulate' is both imperfective and perfective, as shown in Petar upravo 
čestita autoru 'Petar is congratulating the author' and Petar je čestitao autoru tri puta 'Petar has congratulated the author three times.

Perfective verbs in SC are accomplishments, pročitati 'read', achievements, udariti 'hit', and delimitatives, porazgovarati 'talk for a while'. Perfectives may capture different stages in a situation: the beginning, propjevati 'start singing', prozboriti 'start talking', zajecati 'start sobbing', poletjeti 'fly away', and so on; the end, stići 'arrive', izgorjeti 'burn down', pojesti 'eat up', pregristi 'bite through', prekopati 'dig'; the moment when the entire action is exhausted in an instant, pasti 'fall', skočiti 'jump', sjesti 'sit down' and so on; and perfectives which are an activity and an accomplishment in one (also called pofective, delimitative, or episodes in the literature, see Kabakčiev 2000), such as posjedjeti 'sit for a while'.

These complex meanings are expressed by rather complex morphology. Prefixes can be semantically empty, such as the prefix $u$ - in uraditi ${ }^{p f}$ 'do', where the prefix $u$ - simply adds the aspectual information to the base, or semantically full, when the prefix adds a meaning on top of the aspectual meaning of perfectivity, as in preraditi pf 'process', where pre- adds the idea of an action that affects all the parts or aspects of the object. Thus, perfective verbs formed by an empty prefix usually do not allow imperfectivizing suffixes (secondary imperfectivization). For example, uraditi ${ }^{\text {pf ' }}$ do' may not form the imperfective *uradivati. Perfective verbs formed by semantically full prefixes may, but need not, allow imperfectivizing suffixes. For example, preraditi ${ }^{\text {f }}$ 'process' becomes preradivati ipf 'to be processing'. Conversely, prespavati pf 'oversleep' does not allow the secondary imperfective "prespavljivati 'to be oversleeping'.

To make things even more complex, many prefixes are polysemous. The prefix po-, for example, means both 'begin' (poletjeti 'fly away') and 'finish' (pojesti 'eat up'). Other prefixes have many more meanings, such as the prefix $z a$-, which participates in the formation of the following perfective verbs to express: location (behind) in zabaciti 'throw behind', location (around) in zagrliti 'hug', location (to/forward) in zakačiti 'attach', time (start) in zapjevati 'start singing', quantity (intensity) in zagorjeti 'scorch', quantity (intensity+) in zadubiti se 'pore', and manner (change of property) in zacrvenjeti se 'become red' (the examples illustrating the meanings of $z a$ - are taken from Šojat et al. (2012: 120)).

Because these morphosemantic relations are so intricate, some authors suggest it is more natural to analyze Slavic verbs in clusters rather than pairs (Janda 2007). According to this approach, different verbs with 
Vesna Bulatović: English Lexical Correspondents of Aspectual Pairs...

different morphology and aspectual values should be analyzed together if they are semantically related.

\subsection{Aspect in English}

Most English verbs are biaspectual, which means that the same verb can signal both imperfectivity and perfectivity. Even states, as typically imperfective verbs, can have a perfective interpretation in context. For example, the aspectual interpretation of the state want changes from the imperfective in He wanted ${ }^{i p f}$ to move back home to the perfective achievement in All of a sudden, he wanted ${ }^{p f}$ to move back home.

Some states are always imperfective, irrespective of the context. For example, depend ipf, own ipf, and contain ipf always express states, where the focus is on continuity without change. To express change, such as the moment when something suddenly becomes dependent on something or someone, or the moment someone started owning something, English would use a different mechanism, such as become the owner of or become dependent on.

In addition, although some verbs are morphologically not correlated at all, we feel their lexical meaning and aspectual value are connected. One such example is the pair composed of the state know $^{\text {ipf }}$ and the achievement learn ${ }^{\mathrm{pf}}$, which marks the beginning of the state of knowing.

Activities are imperfective but they easily turn to perfective accomplishments in English thanks to the mechanism of temporal bounding. For example, the imperfective draft becomes perfective in the verb phrase draft a contract, which in turn may become imperfective with the addition of a durative adverbial, as in drafted ipf a contract the whole afternoon.

As shown in (1), the transitive verb empty, even when clearly bounded by a specified internal argument, can hardly be classified as either typically perfective or typically imperfective since its aspectual value depends entirely on the broader context.

(1) a. John always emptied ipf the bin at around 9 p.m.

b. John emptied ipf the bin when a police officer called him by his name

c. John emptied ${ }^{p f}$ the bin in less than three minutes

d. John emptied ${ }^{\text {pf }}$ the bin at 9 p.m. sharp 
In (1a), empty is a 'generic cursive' activity, which amounts to a state-like situation. In (1b), it is an activity, in (1c) an accomplishment, and in (1d) an achievement. Example (1b) shows that although the nonprogressive morpheme (in the perfective grammatical aspect) and the specified argument (the bin) yield a perfective meaning, the clause that follows annuls the perfectivity of John emptied ${ }^{p f}$ the bin (or unbounds the accomplishment thus created) and gives the first clause an imperfective (durative) meaning in this case. Examples (1c) and (1d) illustrate the temporal bounding mechanism. To expand on this, the bin in (1c) serves as a telos and bounds both temporally and spatially the action of emptying, while the adverbial in less than three minutes indicates that the bin or its contents were such that it required a certain period of time before it could be emptied. The specific time adverbial at 9 p.m. sharp in (1d) is the component that yields the sentence as perfective. Therefore, empty belongs to all the four situation types and can have either perfective or imperfective aspectual values.

There are also accomplishments whose internal lexical aspectual meaning is perfective, such as master or solve. Although they are transitive verbs and take internal arguments just like activities, they seem to imply, even without the argument, that the terminus has been achieved. Unlike accomplishments that are composed of an activity and a specified argument, e.g. draft a contract, these accomplishments, i.e. master and solve, do not normally take the progressive morpheme because their internal perfectivity would not be compatible with the imperfectivity of the progressive. However, both master and solve require a certain activity over a period of time before they can reach the terminus and it is therefore logical that there must be a means that is used to signal it in English.

Achievements, such as knock pf, change their inherent aspectual nature into the imperfective in phrases including a frequency adverb, such as often knocked ${ }^{\mathrm{ipf}}$, or in the progressive morpheme, such as is knocking ${ }^{\mathrm{ipf}}$. Achievements, such as momentary verbs, always take the non-progressive morpheme to express the perfective aspectual meaning, but the nonprogressive morpheme is still aspectually polysemous in the absence of other clues, as shown in (2).

(2) He knocked ${ }^{\mathrm{pf} / \mathrm{ipf}}$ on the door

Knock in (2) may stand for a single occurrence or for repetition, even without the presence of adverbials expressing such meanings. 
Vesna Bulatović: English Lexical Correspondents of Aspectual Pairs...

Some achievements (often called 'run-up achievements' in the literature), such as die, also include a time before the culmination point, and yet, they remain perfective. If used in the progressive morpheme, the meaning conveys 'is about to', unlike other achievements, such as knock above, which express a series of individual occurrences.

This short overview shows that the clear division of situation types into imperfective states and activities and perfective accomplishments and achievements is valid only out of context since the same verb can express both imperfective and perfective aspectual values. It also shows that in addition to these biaspectual verbs, there are verbs in English that are imperfective or perfective only but may be correlated to other linguistic means that express the other member of the aspectual pair. Since the majority of SC verbs are organized in aspectual pairs, we decided to use SC as the starting point for the identification of their lexical correspondents in English. In $\S 3$ we explain the process and the results.

\section{Study}

Languages lexicalize situations differently. Within the same family even, such as the family of Slavic languages, identical situations are encoded differently. For example, Serbian has intransitive praznovati ipf 'celebrate' only, while Russian has both prazdnovat' ipf and otprazdnovat' pf 'celebrate'. However, another Serbian lexeme with the same sense, transitive slaviti 'celebrate' ${ }^{\text {ipf }}$ has both imperfective and perfectiveforms, slaviti ${ }^{\text {ipf }}$ : proslaviti ${ }^{\text {pf: }}$ proslavljati ipf.

On the other hand, English has multiple means for expressing the same lexical and aspectual meaning. For example, the perfective drink up can also be expressed with drink and a specified argument, such as the beer. Likewise, the beginning of the state be ill, can be expressed with both become ill and fall ill.

Before we explain the methodology of our study, it must be noted that particle verbs, such as drink : drink up, are the lexical means for the expression of aspect in English that are well documented in the literature and thus it is not necessary to recount the details here. With that exception, there have been no attempts, at least to the knowledge of the author, to make a systematic overview of other such means in English. 


\subsection{Methodology}

Two bilingual dictionaries into English (Bujas 1999; Drvodelić 1989) were used both as registers of SC verbs and as sources of their English correspondents. In them, the lexicographers separate the members of SC aspectual pairs and list them in alphabetical order. For example, although pisati ipf and napisati pf 'write' form an aspectual pair, they are listed under the letters $p$ and $n$, respectively. Since we wanted to identify the English correspondents of the SC aspectual pairs, the missing member was identified and its lexical correspondent registered at the same time as the one we encountered first during the search.

Those pairs accepted as the SC aspectual pairs for the purposes of this study were pairs differing only in their aspectual value. For example, although boljeti iff 'ache/hurt' and razboljeti of 'fall ill' have the same base boljeti ipf, they do not form an aspectual pair because they are semantically different (i.e. the prefix raz- is not empty). At the same time, we see razboljeti $s^{p f}$ 'fall ill' as correlated to razboljevati ipf 'fall ill' (a biaspectual verb, in the repetitive, habitual sense here) but also, and more importantly for our study, to bolovati 'be ill' because that is the resultant state of the achievement razboljeti se ${ }^{p f}$ 'fall ill'.

The correspondents that were identified were then inserted into tables with five columns. The first column on the left was reserved for SC verbs (aspectual pairs, biaspectual and monoaspectual verbs). The other columns were for the English lexical correspondents, classified into the following situation types: states, activities, accomplishments, achievements, and episodes.

Most of the English correspondents were biaspectual verbs and were inserted in two columns (e.g. imperfective activities and perfective accomplishments), and a large number in three different columns, for the reasons that are explained in §2.2. above. All the remaining correspondents were then examined and classified according to their form, which ranged from very closely related to not related at all. What they all had in common, however, was a close correlation in their lexical and aspectual meaning.

The correspondents offered by the dictionaries were carefully examined and corrected whenever it was felt that they did not properly reflect the aspectual and lexical meaning of the SC verbs. In addition, where the different senses of a verb lead to different English correspondents, they were recorded as two different verbs. 
The study covered 5,041 verbs and verb pairs in SC and their English correspondents. The next section will present them in a number of groups and sub-groups.

\subsection{Results}

In this section we present evidence to show that in English there are verbs that are not biaspectual, and that they are indeed correlated to some other means that express the other aspectual value of the imperfectivity/ perfectivity dichotomy. We also try to draw certain conclusions about why these English verbs behave differently from the majority of English verbs in the way they express such aspectual distinctions.

Out of 5,041 SC verbs and verb pairs, 459 are biaspectual, and 527 monoaspectual. The biaspectual and monoaspectual verbs together total 986 verbs, which means that the remaining 4,055 verbs had their aspectual counterparts with which they formed aspectual pairs (see Fig. 2). A total of 9,096 verbs were covered by our study. This numerical data can already be used at this stage to make some general observations. For example, it is interesting to note that SC aspectual pairs make up over $80 \%$ of all the verbs covered in the study, and that only $20 \%$ are not organized into aspectual pairs. Biaspectual verbs form roughly $9 \%$ of all the verbs (459 out of 5,041 ), which is contrary to the general impression that biaspectual verbs constitute a small group deviating from the standard. This figure confirms the finding of another recent study (Spasojević, 2015). More importantly, this may suggest that contemporary SC grammars should devote more space and attention to this group of verbs and the mechanism of the compositional aspect in SC. 


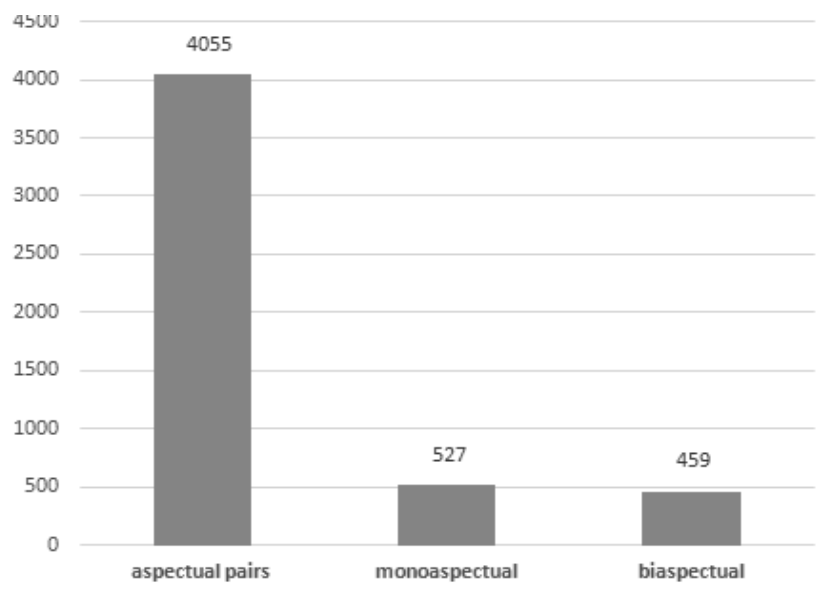

Figure 2. The SC verbs

Out of all the English correspondents of the 5,041 SC verbs and verb pairs, 4,624 , or almost $92 \%$, are biaspectual verbs (see Fig. 3). This shows that this compositional mechanism is indeed the most important mechanism for the understanding of aspect in English. Of the remaining 8\% of the English correspondents, 123 are imperfective only, which leaves 294 verbs for our analysis. Although we have made every effort to accurately classify and count all the verbs, these numbers are given for orientation only.

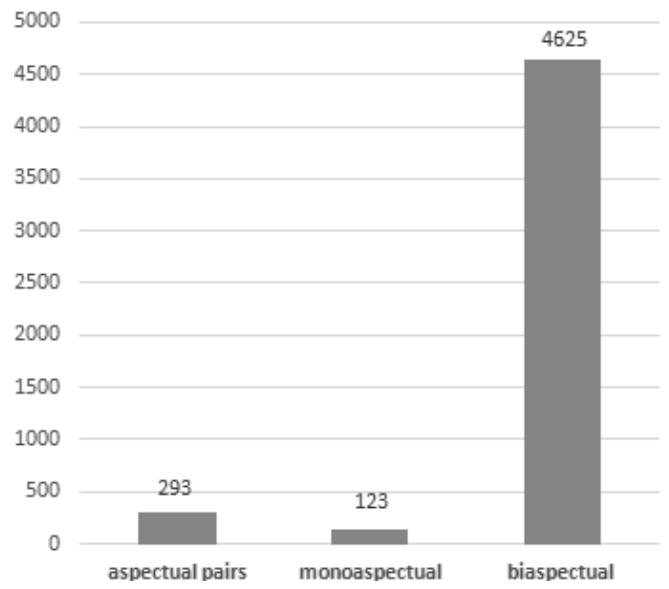

Figure 3. The English correspondents 
In what follows, we give examples of the several types of pairs identified in the analysis.

\section{Group 1}

The pairs in this group are expressed by different lexemes in English. In terms of situation types, there are two types of pairs.

One type is composed of states and achievements, e.g. ache ${ }^{\text {ipf }}:$ smart $^{\mathrm{pf}}$. Achievements include both inceptive and finite verbs, which means that they describe the moment when the related state began or ended.

The other type is composed of activities and accomplishment, e.g. treat ${ }^{\text {ipf }}:$ cure $^{\mathrm{pf}}$.

Many verbs in this group express sensory or cognitive activities. They are private in nature, and if they take objects, they are not easily delimited. For example, if one is suffering or grieving for a while, it is difficult to establish when a change occurred, i.e. when a person got over, or overcame that state. That is probably the reason why English lexicalizes respective situations by different means. The examples of such English pairs are shown on the left, with their correlated SC pairs on the right. In this group, the SC verbs are perfectivized by prefixes that express the beginning or end of the state or activity.

\begin{tabular}{|c|c|c|c|c|}
\hline ache ipf & smart $^{\mathrm{pf}}$ & 'boljeti' ipf & & 'zaboljeti' pf \\
\hline know ipf & learn ${ }^{\mathrm{pf}}$ & 'znati' ipf & & 'saznati' pf \\
\hline dive $e^{\mathrm{ipf}}$ & plunge $^{\mathrm{pf}}$ & 'gnjuriti' ipf & & 'zagnjuriti' pf \\
\hline treat $^{\text {ipf }}$ & cure $^{\mathrm{pf}}$ & 'liječiti' ipf & & 'izliječiti' pf \\
\hline suffer ipf & overcome $^{\mathrm{pf}}$ & 'bolovati' ipf & & 'prebolovati' \\
\hline chase ipf & drive away ${ }^{p f}$ & 'tjerati' ipf & & 'otjerati'pf \\
\hline rieve $^{\text {ipf }}$ & get over pf & 'Žaliti' ipf & & 'prežaliti' pf \\
\hline $\mathrm{rge}^{\mathrm{ipf}}$ & force $^{\mathrm{pf}}$ & 'tjerati' 'ipf & & 'natjerati' pf \\
\hline
\end{tabular}

Group 1 also includes: love ipf 'voljeti' : take a fancy to/grow fond of $\mathrm{pf}^{\mathrm{ff}}$ 'zavoljeti', pursue ipf 'tjerati' : turn away pf 'otjerati'; argue ipf 'dokazivati' : prove ${ }^{\mathrm{pf}}$ 'dokazati', deal ipf 'rješavati': solve ${ }^{\mathrm{pf}}$ 'riješiti', coax ${ }^{\text {ipf } ~ ' u b j e đ i v a t i ' ~: ~}$

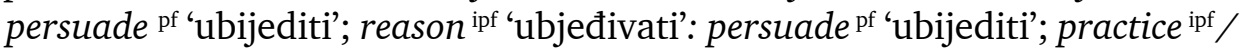
exercise ipf 'vježbati' : master/learn 'uvježbati', wander ipf /stray ipf/ramble ipf 'lutati' : go astray/lose one's way/get lost 'zalutati', be situated ipf 'nalaziti se' : find oneself 'naći se', quarrel ipf/wrangle ipf/bicker ipf 'svađati se' : fall out 'posvađati se', rage ipf/rave ipf 'mahnitati' : get furious/get mad 'pomahnitati', and so on. 
Group 2

This group includes pairs of aspectually related verbs whose members are expressed by different morphological means but always have some elements in common. The imperfective members are states and (physical, cognitive) activities, and the perfective ones are both accomplishments and achievements.

\begin{tabular}{|c|c|c|c|}
\hline sleep $^{\text {ipf }}$ & get some sleep pf & 'spavati' ipf & 'odspavati'pf \\
\hline fight $^{\text {ipf }}$ & fight one's way through $\mathrm{p}^{\mathrm{pt}}$ & 'boriti se' ipf & 'izboriti se'pf \\
\hline sit for an exam ipf & pass an exam ${ }^{\mathrm{pf}}$ & 'polagati' ipf & 'položiti'pf \\
\hline brake ipf & brake to a halt ${ }^{\mathrm{pf}}$ & 'kočiti' ipf & 'zakočiti' pf \\
\hline
\end{tabular}

Other examples include have an effect ipf 'primjenjivati se/imati pravnu snagu' : take effect ${ }^{\mathrm{p}}$ 'primijeniti/stupiti na snagu', be lacking/be short of ${ }^{\text {ipf }}$ 'manjkati': run short of/fall short of ${ }^{\mathrm{pf}}$ 'pomanjkati', agree ipf 'slagati se': come to an agreement pf 'složiti se', and so on.

\section{Group 3}

Here, all the imperfective members are activities, and all the perfective members are accomplishments. The perfectives are resultative verbs, i.e. verbs implying the successful completion of the activity. Most verbs depict various internal, cognitive processes that cannot be measured precisely. It is therefore not possible to speak of an activity, i.e. a process moving step by step towards the objective, using a lexeme that implies completion. In addition, these verbs usually take animate or abstract objects that do not lend themselves easily to any measurement of the impact that the activities have on them.

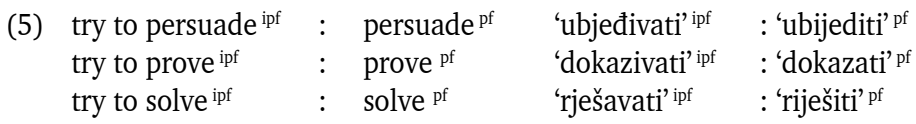

Most SC pairs use stem alternation to produce imperfective and perfective members. Thanks to the -iva/-ava infix, imperfective verbs are formed to express the activity that precedes the moment when the terminus is reached. As shown by the examples in (5), English needs to use try to + verb in order to express that stage.

Other resultatives that form their imperfective counterparts in this way include: tame, resist, improve, appease, engage, assimilate, civilize, wrench, preserve, dishearten, dispirit, demoralize, discourage, deter, entice, allure, decoy, forge, extinguish, coax, elicit, reconcile, devise, contrive, upset, 
accomplish, camouflage, compensate, compromise, concentrate, consolidate, damage, destroy, spoil, legalize, conciliate, motivate, outwit, compel, force, urge, delude, deceive, temper, decipher, solve, find out, unravel, disentangle, dissuade, resist, justify, vindicate, warrant, relax, master, contest, refute, impugn, dispute, adjust, adapt, substantiate, sober up, dissuade, save, rescue, quieten, calm, restrain, soothe, mitigate, embellish, convince, decide, figure out, reassure, reason out, resolve, satisfy, unravel, and so on.

\section{Group 4}

This is a large group of pairs in which the imperfective member is a single verb, and its perfective counterpart consists of the same verb and a particle or a preposition. The particle imposes a boundary on the activity verb. The imperfective members are activities, while the perfective members are accomplishments and achievements.

Two major sub-groups were identified. One includes verbs of movement, where the particle expresses a direction (squat down) or a spatial boundary (push to).

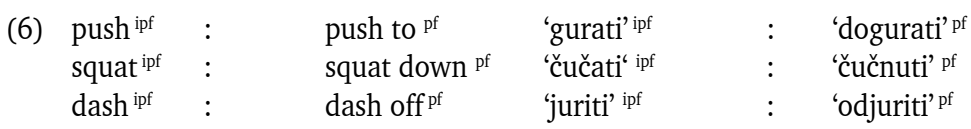

Other examples of verbs of movement include: climb : climb up, sail : sail away, sail : sail out, sail : sail past, crouch : crouch down, walk : walk to, run : run up to, roll : roll up to, crawl : crawl up to, row : row up to, dive : dive in, move : move out, march : march out, march : march past, lie : lie down, run : run away, fly : fly through, fly : fly past, wiggle : wiggle out, dash : dash on, dash : dash off, dash : dash away, gallop : gallop away, rush : rush past, ride : ride past, and the like.

It is clear that all verbs of movement can form several different perfective counterparts so as to specify various directions. This also means that their number is probably much greater than the number identified on the basis of the SC aspectual pairs in our dictionaries.

Another sub-group are verbs of other physical activities, with or without agents, where the meaning of the particle is aspectual and marks the beginning (blaze up) or end (starve out) of the activity, but which can also express the meaning of direction and location, as shown in: 


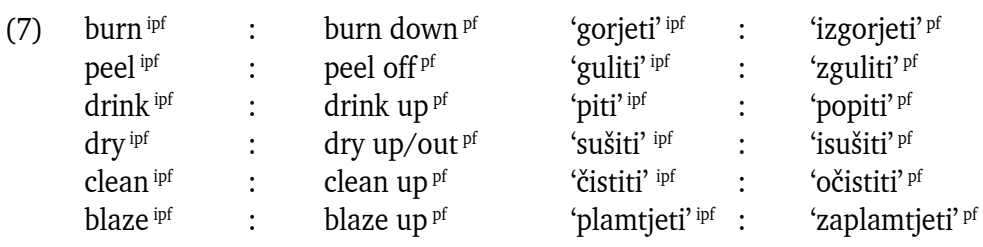

Among other examples, we found the following pairs: burn : burn down; burn : burn away, peel : peel off, peel : peel away, suck : suck out, pump : pump out, chisel : chisel out, drink : drink off, drink : drink up, pay : pay out, dry : dry up, drain : drain off, brush : brush out, brush/brush down, scribble : scribble out, burn : burn down, push : push out, tire : tire out, sweep : sweep up, sweep : sweep away, plough : plough up, grow : grow up, gnaw : gnaw through, burn : burn through, bit: bite through, gamble : gamble away, dig : dig up, doze : doze off, clean : clean up, scrape : scrape off, sew : sew up, tear : tear off, wipe : wipe off, chew : chew up, file : file down, hunt : hunt down, strip : strip down, grind : grind off, chop : chop up, cut : cup up, brush : brush out, brush : brush down, wash : wash out, wash: wash off, wash : wash away, churn : churn up; flame : flame out; blaze : blaze up; ooze : ooze out; leak: leak out, wear : wear away, wear : wear down, flow : flow in, flow : flow out, boil : boil over, shoot : shoot forth, melt : melt away, bleed : bleed out, spin : spin out, melt : melt down, sweep : sweep up, sweep : sweep away, boil : boil over, flame : flame up, and various other examples.

A third, much smaller sub-group was identified which includes verbs of speaking, such as:

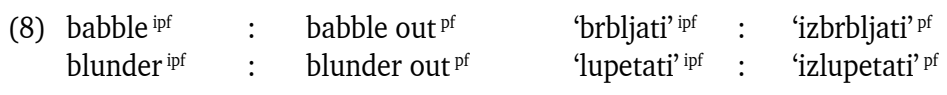

\section{Group 5}

In this group, the imperfective members describe states and activities, while their perfective counterparts are achievements that mark the moment when the change took place, i.e. when the state or activity began. This moment is specified in English with the help of start and begin. These verbs are also called inceptive or inchoative verbs and very often express activities occurring of their own accord. Most express cognitive, auditory and visual perception, as shown in (9) below. The SC perfective verbs all include the prefixes za-, pro-, and po- to mark the moment of change. 
Vesna Bulatović: English Lexical Correspondents of Aspectual Pairs...

\begin{tabular}{|c|c|c|c|c|}
\hline \multirow[t]{6}{*}{ (9) } & bark ${ }^{\text {ipf }}$ & start/begin to bark ${ }^{\mathrm{pf}}$ & 'lajati' ipf & 'zalajati' pf \\
\hline & $\operatorname{cough}^{\text {ipf }}$ & start/begin to cough & 'kašljati' ipf & 'zakašljati se' ${ }^{\mathrm{p}}$ \\
\hline & boil $^{\text {ipf }}$ & start/begin to boil pf & 'ključati' ipf & 'proključati' pf \\
\hline & blow ipf & start/begin to blow ${ }^{\mathrm{pf}}$ & 'duvati' ipf & 'zaduvati' pf \\
\hline & hope ${ }^{\text {ipf }}$ & start/begin to hope $\mathrm{pf}^{\mathrm{pf}}$ & 'nadati se' ipf & 'ponadati se'pf \\
\hline & walk ${ }^{\text {ipf }}$ & start/begin to walk $\mathrm{k}^{\mathrm{pf}}$ & 'hodati' ipf & 'prohodati' pf \\
\hline
\end{tabular}

Other imperfective verbs (activities) whose perfective counterparts are formed in this way are the following: hurt, itch, rule, stink, tingle, tremble, pant, puff, sob, choke, giggle, whine, gurgle, clatter, rattle, quarrel, flap, bleat, mew, hiss, growl, snarl, sob, squeal, bleat, yell, cackle, croak, crow, blow, neigh, rustle, snore, laugh, hum, tremble, tittle, dance, blow, drizzle, limp, float, flutter, swing, say, flow, walk, and others.

\section{Group 6}

In this group of aspectually related verbs, the imperfective members are states composed of be + adjective (which are the correspondents of SC verbs), while the perfective members are achievements that express the moment when the state began, which is expressed with become/get + adjective, as shown in (10). As in the previous groups where the perfective describes the beginning of the state or activity, most SC perfective verbs include the prefixes $z a$ - and raz-.

\begin{tabular}{|c|c|c|c|}
\hline $\begin{array}{l}\text { be worried/worry }{ }^{\text {ipf }} \\
\text { be furious } \\
\text { be sad ipf } \\
\text { be swollen/swell ipf }^{\text {ipf }} \\
\text { be silent }{ }^{\text {ipf }} \\
\text { be part of }{ }^{\text {ipf }}\end{array}$ & $\begin{array}{ll}: & \text { become worried }^{\mathrm{pf}} \\
: & \text { become furious }^{\mathrm{pf}} \\
: & \text { become sad }^{\mathrm{pf}} \\
: & \text { become swollen }^{\mathrm{pf}} \\
: & \text { become silent } \mathrm{pf}^{\mathrm{pf}} \\
: & \text { become part of }^{\mathrm{pf}}\end{array}$ & $\begin{array}{l}\text { 'brinuti' ipf } \\
\text { 'biješnjeti' ipf } \\
\text { 'tugovati' ipf } \\
\text { 'nadimati se' ipf } \\
\text { 'ćutati' ipf } \\
\text { 'pripadati' 'ipf }\end{array}$ & $\begin{array}{l}\text { : 'zabrinuti se'pf } \\
: \text { 'razbiješnjeti' pf } \\
: \text { 'rastužiti se'pf } \\
: \text { 'naduti se'pf } \\
: \text { 'ućutati se'pf } \\
: \text { 'pripasti' pf }\end{array}$ \\
\hline
\end{tabular}

Group 6 is limited only by the number of adjectives that can combine with be on the one hand, and become and get on the other. As demonstrated in the first two pairs, some have multiple forms (be worried, but also worry).

\section{Group 7}

This is a group of aspectually related verbs in which the imperfective member is an activity, and its perfective counterpart is an accomplishment, which in addition to the perfective component in its meaning, always includes the specification of the manner in which the basic activity is conducted. In SC, this additional meaning is expressed most often by the prefixes na- and po- to convey the meaning of 'a sufficient quantity of' and 'one by one' respectively. 


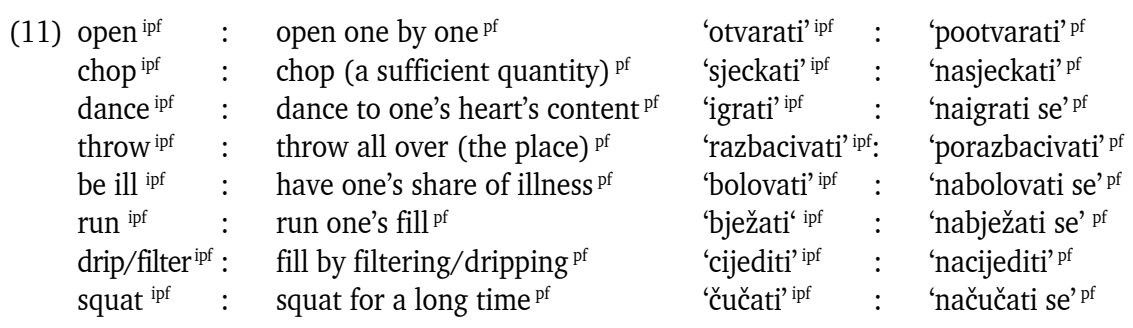

The two prefixes are quite productive and we will list here only a few additional examples of the perfective counterparts of such pairs: root up a sufficient quantity, draw enough water, scream one's fill, distribute a (certain) quantity, get a lungful of (air), throw away, cut off one after another, take one by one by force, and so on.

All the imperfective members of the pairs listed in this group have their perfective counterparts with empty prefixes, e.g. otvarati $i^{\text {ip }}:$ otvoriti ${ }^{\mathrm{pf}}$

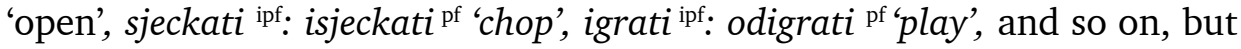
they were included in our analysis because these more expressive perfective counterparts do not have other imperfective counterparts, as is the case for other perfectives with 'full' prefixes. For example, prepisati is related to pisati ipf because, morphologically, pisati ipf is its base, but semantically, prepisati $^{\mathrm{pf}}$ is related to the imperfective prepisivati ${ }^{\mathrm{ipf}}$, and not to pisati ${ }^{\mathrm{ipf}}$.

\section{Group 8}

In the last group of our English lexical correspondents, the perfective members have a perfectivizing affix. The pairs are composed of activities and accomplishments/achievements. The activities express a gradual transition that involves a change of quality. The accomplishments/ achievements express the completion of the transition, which may take place in an instant or may take some time.

In the first sub-group, the imperfective member is expressed using the verb be/grow and an adjective that describes the quality towards which the activity develops. Their perfective counterparts are composed of the adjective that formed the imperfective member and the perfectivizing suffix -en (e.g. blacken from 'black' + 'en'). The meaning of the perfectivizing suffix is 'make' or 'become'. This meaning is identical to that of the perfectivizing SC affixes $z a-$, po-, and $o$ - shown in the examples that follow. The perfective members can also be expressed by become + adjective: 
Vesna Bulatović: English Lexical Correspondents of Aspectual Pairs...

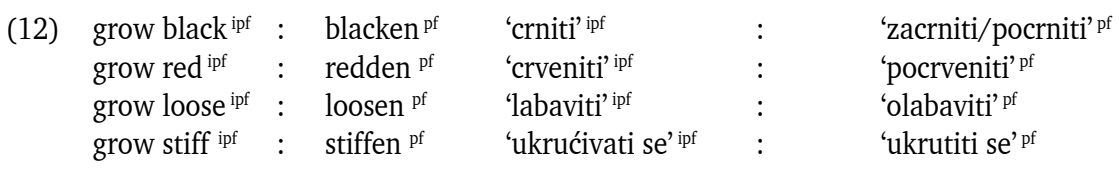

The second sub-group includes the English correspondents that resemble SC aspectual pairs the most because the perfective members, just like in SC, are composed of a prefix (be-, en-, and $a$-) and the base verb. The meaning of the prefix be-is 'cover all over', and the meaning of the prefixes $a$ - and $e n$ - is 'make'.

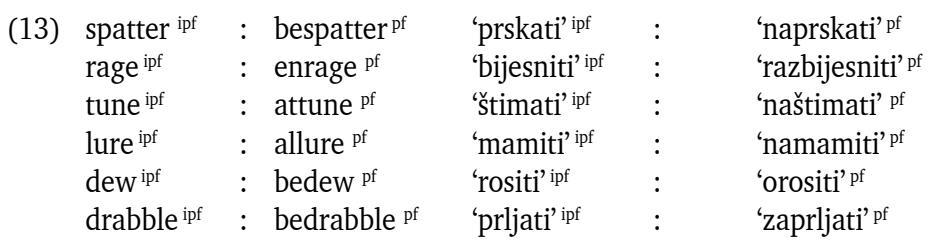

\section{Discussion}

The analysis identified and examined 294 English lexical correspondents of SC aspectual pairs. The number is certainly much larger given that some means, such as those including be/become, start/begin and grow, are very productive and take part in the creation of many more verb phrases that were not included in the dictionaries.

The study provided us with some valuable insights into the aspectual composition of the two verbal systems. The data confirmed that SC and English do indeed use the same set of tools to express imperfectivity and perfectivity, but also revealed that their major tools are in inverse proportion in terms of the number of verbs that use them. In SC, aspectual meanings are dominantly encoded in aspectual pairs, while in around $10 \%$ of cases they are encoded in biaspectual verbs. In English, it is the other way round as in over $90 \%$ of cases, aspectual meanings are encoded in biaspectual verbs, with only around $8 \%$ in aspectually related pairs. Both languages have a small number of cases where different verbs are employed to express different aspectual meanings. It may be concluded, therefore, that in spite of these mismatches, the aspectual systems of the two languages have a great deal in common. 
In terms of the status of the individual members of the pairs, one might argue that they are in fact monoaspectual verbs, i.e. either imperfective only or perfective only. We believe that would not be an appropriate description since unlike the already identified monoaspectual English verbs (e.g. consist) for which no counterpart perfective meaning can be identified irrespective of the form in which that meaning would be expressed, the members of our pairs of lexical correspondents evidently always have a counterpart which differs in the aspectual value only.

It is clear that there are many other ways of lexicalizing some of the imperfective and perfective meanings in English. For example, this study identified smart, started to ache and begin to hurt as perfective correspondents for the state ache, but many native speakers of English would probably use There was a pang or I felt a pang, among a range of other possible expressions. This simply demonstrates that expressing aspectual meanings is important and that languages create many different means for this purpose.

Let us now turn to one of our key questions - why does English have pairs of aspectually related verbs in addition to its biaspectual verbs? The analysis points to the following two reasons.

One is that in a large number of cases these pairs relate to activities that are neither easily observed nor delimited. Such verbs are found in each of our groups, for example ache, suffer, urge, fight, prove, solve, burn, dry, boil, cough, worry, loosen and bedew, to name but a few. Many of them are intransitive and depict situations that are beyond our control. This means that the imperfective and perfective meanings in these situations are quite specific and that they require specific means for their expression. This is in contrast to most other physical activities that have arguments that are easy to observe and delimit (e.g. write a book, sing a song, make a cake, and so on).

The second reason is related to the fact that in many of our pairs the perfective member is an achievement that captures the moment when the state or activity began (drive away, dash off, blaze up, start to cough, become $s a d$, and various others). This is, in some senses, to be expected, given that, with a few exceptions, English does not have verbal morphology that would help specify these particular meanings. That is why periphrastic expressions are used instead.

As mentioned previously, bilingual dictionaries were used primarily as registers of SC verbs, and as primary sources of the English lexical 
Vesna Bulatović: English Lexical Correspondents of Aspectual Pairs...

correspondents that were always carefully examined. The analysis points to a number of things. First, the English correspondents in the dictionaries are sometimes incorrect. For example, the correspondents offered for SC liječiti ipf 'treat' include 'treat medicinally (medically)'; 'treat a person for ... ${ }^{\text {ipf'; }}$ 'medicate ${ }^{\mathrm{ipf}}$, but also 'cure medically ${ }^{\mathrm{pf}}$ ', 'cure of a disease ${ }^{\mathrm{pf} \text { ', }}$, which is wrong since cure ${ }^{\mathrm{pf}}$ is a resultative verb implying the successful completion of the activity, which is not the aspectual meaning of liječiti ipf. Second, the use of begin/start to in the expression of inceptive verbs, such as start to ache, is often too general in the formation of the English correspondents and given priority over inherently perfective lexemes, such as smart. Third, the lexical entries provide no aspectual information for English verbs that are not biaspectual. For example, it would be very useful if the English correspondents of SC ubijediti 'convince, persuade' came with the note that they are perfective only.

\section{Conclusion}

The study has given us a better insight into the structure of the two verbal systems and confirmed that the two languages use the same set of instruments, but with a different order of frequency.

For SC, the main conclusion is that as many as $10 \%$ of its verbs are biaspectual, which is not properly reflected in grammar reference works. It is common knowledge that in SC grammars, a great deal of space is always devoted to prefixation and stem alternation, while biaspectual verbs are barely mentioned and illustrated through only a few examples (usually of foreign origin). Given that they represent $10 \%$ of the total, biaspectual verbs deserve a better description.

The study has also demonstrated that around 10\% of English verbs form pairs of aspectually related verbs. Eight different groups have been established in our analysis, featuring verbs that often express an action that is difficult, if not impossible, to measure, delimit, or control. That is probably the reason why English uses different lexical means to express the imperfective and perfective meanings related to such actions. Another major group is that of those inchoative verbs that mark the beginning of a state or an activity. The reason why the perfective counterparts to these imperfective states and activities are expressed periphrastically is that the morphological means for the expression of this meaning in English is often insufficient. 
We hope to have responded to our first three questions from $\S 1$. As for the last question, one further step in our contribution to the description of English could be to attempt to verify our pairs in electronic corpora of English or through tests designed to obtain such verification directly from native speakers of English.

We also hope some of our suggestions will be useful for dictionaries, reference grammars, and EFL teachers, but also EFL learners, who often overgeneralize the use of biaspectual verbs in the explication of aspectual meanings in English.

\section{References}

Arad, M. (1998). VP-Structure and the Syntax-Lexicon Interface. MIT Occasional Papers in Linguistics 16. Cambridge, MA: MIT Department of Linguistics.

Brinton, L. (1988). The Development of English Aspectual Systems. Cambridge: Cambridge University Press.

Bujas, Ž. (1999). Veliki hrvatsko-engleski rječnik. Zagreb: Nakladni zavod Globus.

Bybee, J. L. and O. Dahl (1989). The creation of tense and aspect systems in the languages of the world. Studies in Language, 13(1), 51-103.

Comrie, B. (1985). Tense. Cambridge: Cambridge University Press.

Comrie, B. (1976). Aspect. An Introduction to the Study of Verbal Aspect and Related Problems. Cambridge: Cambridge University Press.

Dahl, O. (1984). Perfectivity in Slavonic and Other Languages. In: C. de Groot and H. Tommola (eds.), Aspect Bound: A Voyage into the Realm of Germanic, Slavonic and Finno-Ugrian Aspectology (Proceedings from the First Scandinavian Symposium on Aspectology in Vasa, 26-28 August 1983), Dordrecht-Holland/Cinnaminson: Foris Publications, 3-22.

Dahl, O. (1985). Tense and Aspect Systems. Oxford: Basil Blackwell.

Dowty, D. R. (1977). Toward a Semantic Analysis of Verb Aspect and the English 'Imperfective' Progressive. Linguistics and Philosophy, 1, 45-78.

Drvodelić, M. (1989). Hrvatsko ili srpsko engleski rječnik. Zagreb: Školska knjiga.

Galton, A. (1984). The logic of aspect. An axiomatic approach. Oxford: Clarendon Press. 
Vesna Bulatović: English Lexical Correspondents of Aspectual Pairs...

Groot, C. de and H. Tommola (eds.) (1984). Aspect Bound: A Voyage into the realm of Germanic, Slavonic and Finno-Ugrian Aspectology. Proceedings from the First Scandinavian Symposium on Aspectology in Vaasa, 26-28 August 1983). Dordrecht-Holland/Cinnaminson, Foris Publications.

Hlebec, B. (1990). Aspects, Phases and Tenses in English and SerboCroatian. Grazer Linguistische Monographien 8. Graz: Institut für Sprachwissenschaft der Universität Graz.

Janda, L. A. (2007). Aspectual clusters of Russian verbs. Studies in Language, 31, 607-648.

Kenny, A. (1963). Action, Emotion, and Will. London: Routledge and Kegan Paul.

Kabakčiev, K. (2000). Aspect in English: A "Common-Sense" View of the Interplay between Verbal and Nominal Referents. Studies in Linguistics and Philosophy 75. Dordrecht: Springer.

Lakoff, G. and M. Johnson (1980). The Metaphorical Structure of the Human Conceptual System. Cognitive Science, 4, 195-208.

Langacker, R. W. (1987). Foundations of Cognitive Grammar, vol. 1, Theoretical Prerequisites.

Stanford: Stanford University Press.

Langacker, R. W. (1991). Foundations of Cognitive Grammar, vol. 2, Descriptive Application. Stanford: Stanford University Press.

Langacker, R. W. (2008). Cognitive Grammar. Oxford: Oxford University Press.

Mourelatos, A. (1978). Events, Processes and States. Linguistics and Philosophy, 2, 415-434.

Novakov, P. 1991. Glagolski vid i Aktionsart u engleskom i srpskohrvatskom jeziku. [Aspect and Aktionsart in English and Serbo-Croatian]. PhD dissertation. Faculty of Philosophy, University of Novi Sad.

Partee, B. H. (1999). Nominal and temporal semantic structure: Aspect and quantification. In: E. Hajičová, T. Hoskovec, O. Leška and P. Sgall (eds.), Prague Linguistic Circle Papers, 3, 91-108.

Rothstein, S. (2001). What are Incremental Themes? In: J. Gerhard, A. S. Strigin, S. Wilder and N. Zhang (eds.), ZAS Papers in Linguistics, 22, 139-157.

Ryle, G. (1949). The Concept of Mind. London: Barnes and Noble.

Spasojević, M. Lj. (2015). Dvovidski glagoli u savremenom srpskom jeziku [Biaspectual verbs in modern Serbian]. PhD dissertation. Faculty of Philology, University of Belgrade. 
Šojat, K. et al. (2012). Derivational and Semantic Relations of Croatian Verbs. Journal of Language Modelling, 1, 111-142.

Thelin, N. B. (1990). Verbal Aspect in Discourse: on the State of the Art. In: N. Thelin (ed.), Verbal Aspect in Discourse. Contributions to the Semantics of Time and Temporal Perspective in Slavic and Non-Slavic Languages, Amsterdam/Philadelphia: John Benjamins Publishing Co, 3-88.

Vendler, Z. (1967). Verbs and Times. In: Z. Vendler (ed.), Linguistics in Philosophy, Ithaca, NY: Cornell University Press, 97-121.

Verkuyl, H. J. (1972). On the Compositional Nature of the Aspects. Dordrecht: D. Reidel.

Verkuyl, H. J. (1989). Aspectual Classes and Aspectual Composition. Linguistics and Philosophy, 12(1), 39-94.

Zandvoort, R. W. (1962). Is 'Aspect' an English Verbal Category? Gothenburg Studies in English, 14, 1-20.

Zhang, L. (1995). A Contrastive Study of Aspectuality in German, English and Chinese. New York/Washington/San Francisco: Peter Lang.

Received: 4 February 2019

Accepted for publication: 20 April 2020

Весна Булатовић

\section{ЕНГЛЕСКИ ЛЕКСИЧКИ КОРЕСПОНДЕНТИ ВИДСКИХ ПАРОВА У СРПСКОХРВАТСКОМ ЈЕЗИКУ}

\section{Сажетак}

Рад се бави енглеским лексичким кореспондентима видских парова у српскохрватском (CX). СХ и енглески су дијаметрално супротни у погледу начина исказивања граматичке категорије вида, због чега се посматрају као типични представници ‘видских', односно 'невидских' језика. У СХ, видске разлике изражавају се сљедећим средствима: а) видским паровима сродних лексема, као нејчешћим средством, затим б) двовидским глаголима и, на крају в) видским паровима несродних лексема. Наша анализа показује да 'невидски' енглески језик користи иста три средства, али обрнутим редосљедом у погледу учесталости. Највећи број енглеских глагола је двовидски, што значи да њихово видско тумачење зависи од неколико фактора изван глаголске лексеме. Предмет наше анализе су управо ова 
Vesna Bulatović: English Lexical Correspondents of Aspectual Pairs...

друга два средства. На основу лексичких и морфолошких односа међу парњацима анализом је издвојено неколико подтипова лексичких средстава за изражавање видских разлика у енглеском.

Кључне ријечи: свршеност, несвршеност, вид, лексички вид, видски пар 